鹿児島県に扣ける飲用水の成分と循環系疾患

\title{
死亡との関係
}

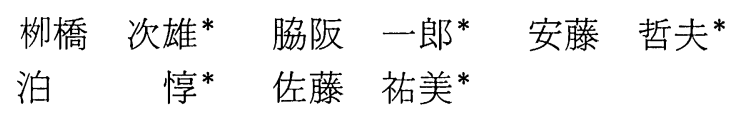

\section{Relationship between Chemical Constituents in Drinking Water and Mortality Rates from Cerebro-Cardio-Vascular Diseases in Kagoshima Prefecture}

\section{Tsuguo YANAGIHASHI*, Ichiro WAKISAKA*, Tetsuo ANDO*, Tsutomu TOMARI* and Masumi SATO*}

Based on the death records covering a 15-year period 1971 to 1985 , the standardized mortality ratios (SMRs) for selected cerebro-cardio-vascular diseases were calculated for each of 96 local community units (14 cities, 73 towns and 9 villages) in Kagoshima prefecture. These local communities characterized by the SMRs for different categories of cerebro-cardio-vascular disease were classified by the cluster analysis using the statistical package (Ward) on computer and the geographic difference in the characteristic of death rates from these diseases were explained by the ionic concentrations in local drinking water. Results obtained are as follows;

1) With a criterion of 7.5 in the cluster analysis, the 96 local communities were classified into five regional groups (Group I, II, III, IV and V), each of which could be regarded as the group of local communities with similar characteristics of SMRs for different categories of cerebro-cardio-vascular disease. A total of 33 local communities belonged to Group I, 16 to Group II, 25 to Group III, 11 to Group IV and 11 to Group V, respectively. All the local communities in Group IV were on the remote islands.

2) The values of SMRs for cerebrovascular disease in Groups I, II and III were higher than the expected level of 1 while those in Group IV and V were less than this level. For cerebral hemorrhage, the values of SMRs were higher than 2 in Group II, higher than 1 in Groups I, III and V and below 1 in Group IV. For cerebral infarction, the values of SMRs were higher than 1 in only Group III and less than 1 in the other Groups. For hypertensive disease, the values of SMRs were higher than 2 in Group V, higher than 1 in Group I, II and III, and less than 1 in Group IV. For ischemic heart disease, the values of SMRs were higher than 1 in only Group III and less than 1 in the other Groups. For other heart disease, the values of SMRs were higher than 1 in Groups I, II, III and V and less than 1 in only Group IV. Therefore, the values of SMRs for all of cerebro-cardio-vascular diseases

* 鹿児島大学医学部公衆衛生学教室

* Department of Public Health, Faculty of Medicine, Kagoshima University 
were higher than 1 in Group III and less than 1 in Group IV.

3) On a Group basis, significant negative correlations were noted between SMRs of cerebrovascular disease and $\mathrm{Mg}, \mathrm{Ca}, \mathrm{Mg}+\mathrm{Ca}$ or $\mathrm{Ca} / \mathrm{K}$ in drinking water, between SMRs of ischemic heart disease and $\mathrm{Mg}$ or $\mathrm{Mg}+\mathrm{Ca}$, and between SMRs of other heart disease and $\mathrm{Na}, \mathrm{Mg}, \mathrm{Ca}, \mathrm{Cl}$ or $\mathrm{Mg}+\mathrm{Ca}$. Similar negative correlations existed between SMRs of selected cerebro-cardio-vascular diseases and selected ionic concentrations, on a community basis for the 96 units.

4) Results of the multiple regression analyses showed that $\mathrm{Ca}$ and $\mathrm{Ca}-\mathrm{Na}$ in drinking water were positively associated with deaths from cerebrovascular disease while $\mathrm{Cl}$ was negatively associated with that factor. They also showed that $\mathrm{Na}$ was negatively associated with deaths from cerebral hemorrhage, $\mathrm{K}$ was positively while $\mathrm{Cl}$ and $\mathrm{Cl} / \mathrm{K}$ were negatively associated with deaths from cerebral infarction, $\mathrm{Cl}$ was negatively associated with deaths from hypertensive disease, $\mathrm{Mg}, \mathrm{Ca}$ and $\mathrm{Mg} / \mathrm{Ca}$ were negatively associated with deaths from ishemic heart disease, and $\mathrm{Ca}$ and $\mathrm{Na}$ were negatively associated with deaths from other heart disease, respectively.

\section{I は じめに}

我が国の死亡原因順位の第一位は1981年以来悪 性新生物になったが, 脳血管疾患, 心疾患及び高 血圧性疾患を併せた循環系疾患の死亡割合は総死 亡の約 $40 \%$ と最も大きな割合を占めている（国民 衛生の動向, 1988).このことは, 我が国では急速 な人口構成の高齢化を迎えていることもあって, 循環系疾患研究の重要性が末だな拈ざりに出来な い理由の一つでもある。

鹿児島県は首都圏から遠く, 農業以外の産業に 乏しいために若年労働力を求める大都市圏への流 出が著しい, 県内的にみても, 県庁所在の鹿児島 市とそれに隣接する少数の町を除けば殆どの市町 村では人口の社会減によって過疎が進行してい る.このよらなこともあって, 人口構成で高齢者 の占める割合も市町村によっては様々であり, そ のことが脳血管疾患を初めとする循環系疾患の死 亡割合の地域差として反映されているとも云える だろう.

ところで, 鹿児島県の行政区は南北約 $600 \mathrm{~km}$, 東西約 $150 \mathrm{~km}$ の範囲にあり, しかも離島や山間僻 地が多いことから, 地勢, 地質, 土壤の差異によっ て各市町村で供給されている领料水に含まれるイ
オン成分にも地域による特徴があるだろう。水は 人間の生存にとって欠かすことのできない貴重な 物質であり，長い人生において継続的に摄取する 飲料水は膨大な量となるため, 含有イオンが身体 に与える作用も間接的であれ, 直接的であれ, 存 在するものと考えられる.

本研究は, 鹿児島県における種々の循環系疾患 死亡者数を市町村単位で求め, その SMR 值を特 性值として市町村のクラスター分析を行ない, 各 疾患の死亡パタンに類似性をもった市町村群の特 徵について, 飲料水の成分に関する諸因子で説明 することを試みたものである。

\section{II 分 析方 法}

鹿児島県下全96市町村のそれぞれについて循環 系疾患の標準化死亡比 (SMR) を算出するにあ たっては, 人口規模が小さい自治体が多いので, 昭和46年 (1971) から昭和60年 (1985) までの 15 年間の死亡数の合計を用いた。これに対応する全 国の死因別死亡率と各市町村の人口構成を用い て, 間接法によって標準化死亡比を求めた。対象 とする循環系疾患は, 脳出血, 脳梗塞, 高血圧性 疾患, 虚血性心疾患及びその他の心疾患の 5 種と した。これら疾患の SMR を特性值として, Ward 
法によるクラスター分析によって全96市町村の類 型化を行なった。

一方，この死亡パタンを説明する因子として， 各市町村の人口密集地区から 1 カ所ずつ公共水道 水を昭和 62 年 12 月から昭和 63 年 3 月までの期間で 晴天の続いた日に採取し，これに含まれる $\mathrm{Na}^{+}$， $\mathrm{K}^{+}, \mathrm{Mg}^{++}, \mathrm{Ca}^{++}$量を全自動高速イオンクロマト グラフ(東洋曹達 HLC-601) で測定し，併せて $\mathrm{Cl}^{-}$ をMohr 法で測定した．水道水の採取にあたり， 一自治体に一公共上水道施設が設置されたところ は問題ないが, 行政所管区域が広く, 数力所の水 道施設を持つところや，離島の町村の中には数カ 所の小島からなり, 各島毎に水道が設置されてい るところでは，どの島の水道水を試料にするか問 題となる．基本的には人口密集地区を選んだが， 十島村は火山島の中之島, 三島村ではやはり火山 島の硫黄島の深井戸を水源とする公共簡易水道水 を試料とした。

\section{III 結 果}

Fig. 1 はクラスター分析の結果をデンドログ ラムで示したものである.群分けの距離基準を 7.5 としたとき，96市町村は大別して 5 群に分類され る.これを地域図として示したものが Fig. 2であ り， I, II, III, IV, V 群と名付けた。 I 群は県 都鹿児島市を含む 33 市町村で最も大きく，7市が 含まれ，離島にあるものは名瀬市，瀬戸内町，上 䝵村の 1 市, 1 町, 1 村である. II群は 3 市 13 町 (16市町)で村は含まれず，離島にあるものは西之 表市と屋久町の 1 市 1 町である. III群の 25 市町村 は大隅半島に集中しており，離島にあるものは 3 町 1 村である.IV群の 8 町 3 村 (11町村) は総て が薩南の離島にある。V群は 8 町 3 村 (11町村) で,このらち離島に所属するのは 1 町 4 村である. 各群は循環系死亡パタンに類似性を持つ市町村の 集合と見ることがでさるので, 群ごとに所属市町 村の SMR 值の単純平均を求め, これを群ごとの 循環系死亡パタンとして Table 1 の上段に示し, 下段にはそれに対応する市町村ごとの飲料水中イ オン含有量を平均値で示した。

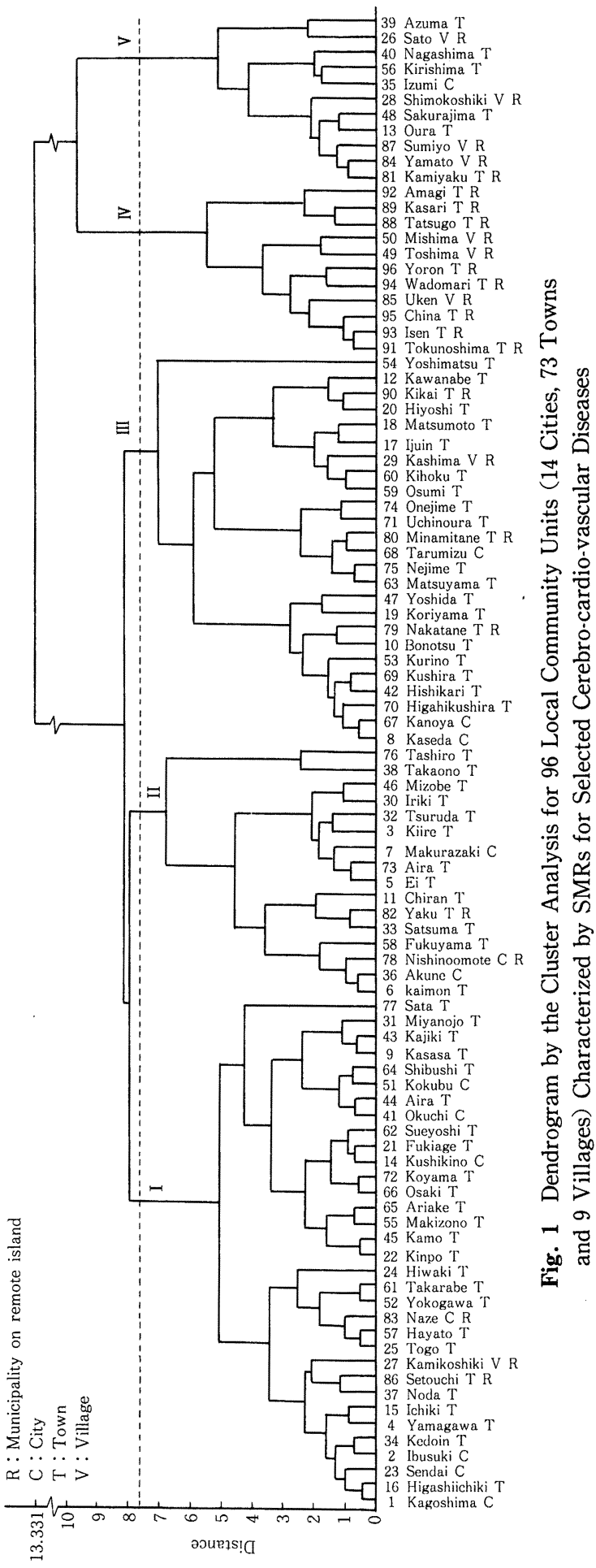




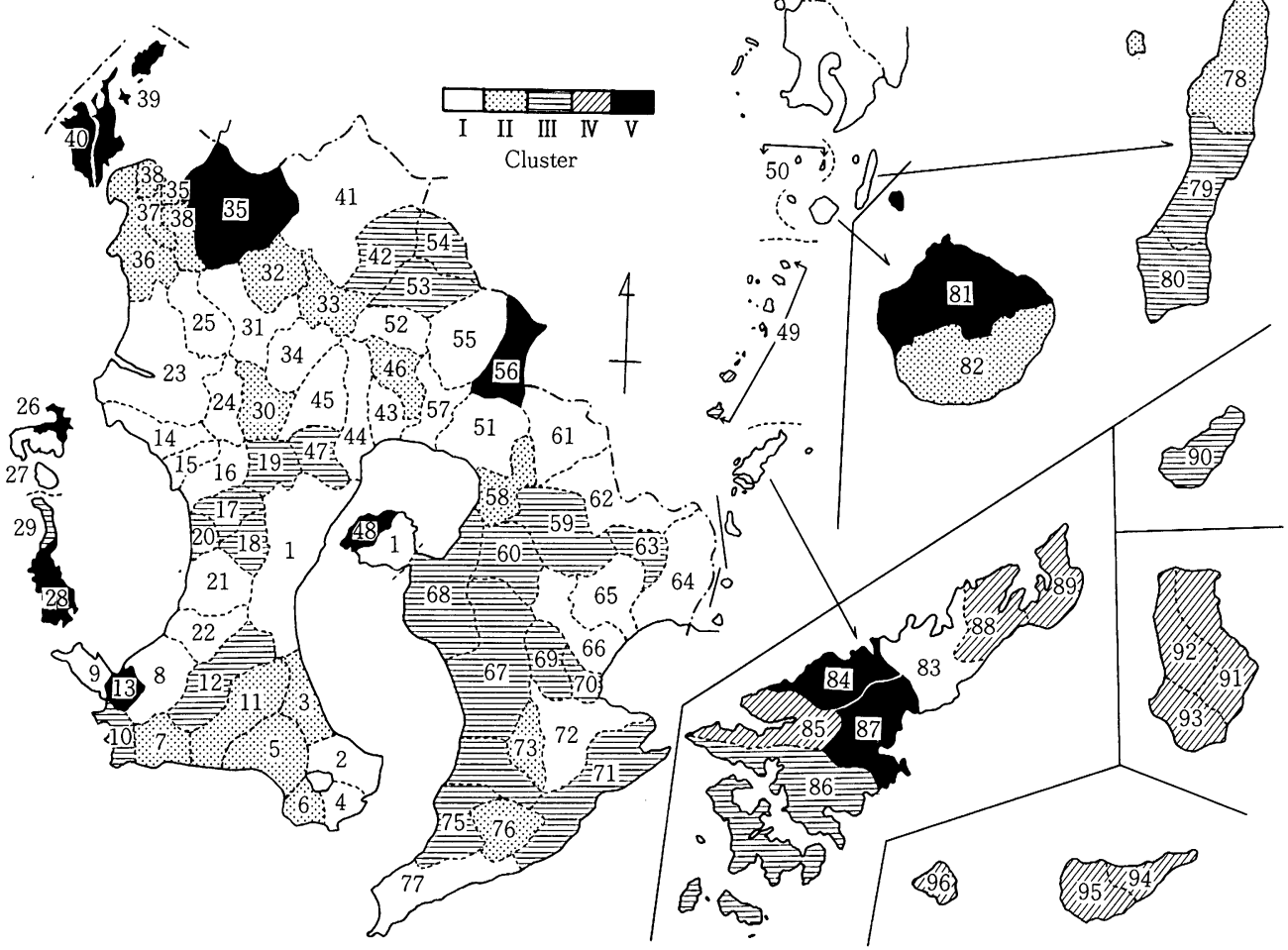

Note: The numbers represent corresponding local communities in Fig. 1

Fig. 2 Regional Groups (Clusters I-V) Classified by the Cluster Analysis

Table 1 Patterns for the Standardized Mortality Ratios (SMRs) of Selected Cerebro-cardiovascular diseases and for the Ionic Compositions within the Cluster

\begin{tabular}{llrrrrrr}
\hline & Cluster & I & II & III & IV & V & Total \\
\hline & Cerebrovascular disease & 1.163 & 1.195 & 1.298 & 0.762 & 0.985 & 1.137 \\
& Cerebral hemorrhage & 1.339 & 2.023 & 1.692 & 0.940 & 1.116 & 1.474 \\
Cerebro-cardio- & Cerebral infarction & 0.818 & 0.706 & 1.078 & 0.385 & 0.569 & 0.789 \\
vascular disease & Hypertensive disease & 1.408 & 1.917 & 1.276 & 0.738 & 2.668 & 1.526 \\
& Ischemic heart disease & 0.809 & 0.899 & 1.115 & 0.429 & 0.708 & 0.849 \\
& Other heart disease & 1.085 & 1.155 & 1.095 & 0.881 & 1.015 & 1.068 \\
\hline & $\mathrm{Na}$ & 0.524 & 0.366 & 0.446 & 0.982 & 0.477 & 0.524 \\
& $\mathrm{~K}$ & 0.083 & 0.049 & 0.056 & 0.046 & 0.053 & 0.063 \\
Ionic composition & $\mathrm{Mg}$ & 0.171 & 0.136 & 0.140 & 0.252 & 0.182 & 0.168 \\
& $\mathrm{Ca}$ & 0.279 & 0.261 & 0.291 & 1.039 & 0.395 & 0.380 \\
& $\mathrm{Cl}$ & 0.612 & 0.440 & 0.524 & 1.279 & 0.576 & 0.633 \\
& $\mathrm{Ca}-\mathrm{Na}$ & -0.244 & -0.105 & -0.155 & 0.057 & -0.082 & -0.145 \\
& $\mathrm{Mg}+\mathrm{Ca}$ & 0.550 & 0.397 & 0.431 & 1.291 & 0.577 & 0.547 \\
& $\mathrm{Na} / \mathrm{K}$ & 8.877 & 18.467 & 10.145 & 30.898 & 33.803 & 16.185 \\
& $\mathrm{Ca} / \mathrm{K}$ & 4.461 & 11.960 & 7.221 & 34.284 & 14.924 & 11.046 \\
& $\mathrm{Mg} / \mathrm{Ca}$ & 0.633 & 0.524 & 0.569 & 0.512 & 0.648 & 0.586 \\
\hline
\end{tabular}


Table 2 Correlation Coefficients between SMRs for Selected Cerebro-cardio-vascular Diseases and Indices for Ionic Composition in Drinking Water

\begin{tabular}{|c|c|c|c|c|c|c|c|c|c|c|c|}
\hline \multirow{2}{*}{\multicolumn{2}{|c|}{$\begin{array}{l}\text { Type of Crerebro-cardio- } \\
\text { vascular diseases }\end{array}$}} & \multicolumn{10}{|c|}{ Ionic composition } \\
\hline & & $\mathrm{Na}$ & K & $\mathrm{Mg}$ & $\mathrm{Ca}$ & $\mathrm{Cl}$ & $\mathrm{Ca}-\mathrm{Na}$ & $\mathrm{Mg}+\mathrm{Ca}$ & $\mathrm{Na} / \mathrm{K}$ & $\mathrm{Ca} / \mathrm{K}$ & $\mathrm{Mg} / \mathrm{Ca}$ \\
\hline \multirow{6}{*}{$\begin{array}{l}\text { Cluster } \\
\text { basis } \\
(n=5)\end{array}$} & Ceret & -0.835 & 0.392 & $-0.954^{*}$ & $-0.903^{*}$ & -0.870 & -0.823 & $-0.911^{*}$ & -0.825 & $-0.913^{*}$ & 0.205 \\
\hline & Cerebral hemorrhage & -0.726 & -0.027 & -0.877 & -0.704 & -0.739 & -0.453 & -0.761 & -0.601 & -0.599 & -0.268 \\
\hline & Cerebral infarction & -0.647 & 0.428 & -0.803 & -0.751 & -0.692 & -0.784 & -0.753 & -0.857 & -0.836 & 0.224 \\
\hline & Hype & -0.699 & -0.046 & -0.434 & -0.560 & -0.649 & -0.220 & -0.580 & 0.303 & -0.383 & 0.593 \\
\hline & Ischen & -0.811 & 0.240 & $-0.934^{*}$ & -0.846 & -0.838 & -0.718 & $-0.880^{*}$ & -0.743 & -0.844 & 0.165 \\
\hline & Other $\mathrm{h}$ & $-0.912^{*}$ & 0.327 & $-0.971^{* *}$ & $-0.938^{*}$ & $-0.932^{*}$ & -0.764 & $-0.947^{*}$ & -0.684 & -0.873 & 0.175 \\
\hline \multirow{6}{*}{$\begin{array}{l}\text { Community } \\
\text { basis } \\
(n=96)\end{array}$} & & $-0.418^{* *}$ & 069 & -0.171 & $-0.205^{*}$ & $-0.456^{* *}$ & 0.107 & $-0.220^{*}$ & $-0.203^{*}$ & $-0.209^{*}$ & -0.045 \\
\hline & Cerebral hemorrhage & $-0.360^{* *}$ & -0.140 & $-0.258^{* *}$ & $-0.233^{*}$ & $-0.343^{* *}$ & 0.028 & $-0.263^{* *}$ & -0.009 & -0.078 & -0.068 \\
\hline & Cerebral infarction & -0.194 & 0.195 & -0.027 & -0.144 & $-0.251^{*}$ & -0.006 & -0.135 & $-0.330^{* *}$ & $-0.307^{* *}$ & -0.003 \\
\hline & Hypertensive disease & -0.166 & -0.022 & -0.041 & -0.162 & -0.198 & -0.049 & -0.156 & -0.003 & -0.136 & 0.126 \\
\hline & Ischemic heart disease & $-0.320^{* *}$ & 0.003 & $-0.255^{*}$ & $-0.303^{* *}$ & $-0.306^{* *}$ & -0.083 & $-0.326^{* *}$ & -0.131 & $-0.237^{*}$ & -0.120 \\
\hline & Other heart disease & $-0.219^{*}$ & 0.020 & -0.166 & -0.156 & $-0.209^{*}$ & 0.000 & -0.175 & -0.179 & -0.188 & -0.022 \\
\hline
\end{tabular}

Note: The significance of the correlation coefficient is shown by $\left(^{*}\right)$ or $\left(^{* *}\right), p<0.05$ and 0.01 , respectively

循環系疾患死亡パタンについては，I 群は県平 均パタンと類似しており，II群は脳出血及び高血 圧性疾患の SMR 值が高くて脳梗塞の SMR 值が 低いが，やはり I 群と同様に県平均パタンと類似 している。III群は全ての循環系疾患の SMR 值が 全国標準值の 1 を超えており，高血圧性疾患以外 は県平均よりも高く, 特に脳梗塞, 虚血性心疾患 の SMR 值が高い.IV群の SMR 值は総てが 1 末 満であり，かつ県平均に比べても低い值である. $\mathrm{V}$ 群もIV群とほぼ同様であるが，高血圧性疾患の SMR 值は県平均の1.7倍と高い.

イオン含有量について目立つのは薩南の離島の 市町村からなるIV群があり, この群では $\mathrm{Na}^{+}$, $\mathrm{Mg}^{++}, \mathrm{Ca}^{++}, \mathrm{Cl}^{-}$濃度がいずれも県平均值よりも 高く, 一方 $\mathrm{K}^{+}$濃度が低い. II 群では $\mathrm{Na}^{+}, \mathrm{K}^{+}$, $\mathrm{Mg}^{++}, \mathrm{Ca}^{++}, \mathrm{Cl}^{-}$の総てが県平均値より低い. $\mathrm{Na}^{+} / \mathrm{K}^{+}$は離島の町村を多く含むIV群とV群にお いて県平均の約 2 倍の值を示している。また，ど の群についても $\mathrm{Na}^{+} よ り も \mathrm{Cl}^{-}$濃度の方が高い が，96市町村を個別に見ると $\mathrm{Cl}^{-} よ り も ~ \mathrm{Na}^{+}$の方 が濃度が高い市町村は20あり，この中には離島部 の市町村は一つも含まれていなかった。

Table 2 は各水中イオン濃度或いはその差・ 和・比と各疾患の SMR 值との相関マトリックス をかかげたものである。上段は群単位で，下段は 96の市町村単位で求めた相関係数である。群単位
で見た場合には，脳血管障害死亡率と $\mathrm{Mg}^{++}$, $\mathrm{Ca}^{++}, \mathrm{Mg}^{++}+\mathrm{Ca}^{++}$及び $\mathrm{Ca}^{++} / \mathrm{K}^{+}$との間で虚血性 心疾患死亡率と $\mathrm{Mg}^{++}$或いは $\mathrm{Mg}^{++}+\mathrm{Ca}^{++}$との間 で, その他の心疾患の死亡率と $\mathrm{Na}^{+}, \mathrm{Mg}^{++}, \mathrm{Ca}^{++}$, $\mathrm{Cl}^{-}$及び $\mathrm{Mg}^{++}+\mathrm{Ca}^{++}$との間で，いずれも有意の 負相関があり，有意の正相関を示したものはな かった.

市町村単位で求めた各疾患死亡率とイオン濃度 との相関を見ると, $\mathrm{Na}^{+}$と脳血管障害, 脳出血, 虚 血性心疾患，その他の心疾患との間には有意の負 相関が， $\mathrm{Mg}^{++}$は脳出血及び虚血性心疾患との間 で負相関があり, 更に $\mathrm{Ca}^{++}$は脳血管障害, 脳出血 及び虚血性心疾患との間で負相関, $\mathrm{Cl}^{-}$は脳血管障 害, 脳出血, 脳梗塞, 虚血性心疾患及びその他の 心疾患と有意の負相関があり，また $\mathrm{Ca}^{++}+\mathrm{Mg}^{++}$ の場合は $\mathrm{Ca}^{++}$場合と同様で脳血管障害, 脳出 血，虚血性心疾患との間で負相関があった。その 外, $\mathrm{Na}^{+} / \mathrm{K}^{+}$と脳血管障害及び脳梗塞との間にも 有意の負相関が見られ，更にまた， $\mathrm{Ca}^{++} / \mathrm{K}^{+}$と脳 血管障害, 脳梗塞及び虚血性心疾患との間にも有 意の負相関が見られた。従って，群単位，市町村 単位に共通して有意相関が見られたのは，脳血管 障害と $\mathrm{Ca}^{++}, \mathrm{Mg}^{++}+\mathrm{Ca}^{++}$或いは $\mathrm{Ca}^{++} / \mathrm{K}^{+}$, 虚血 性心疾患と $\mathrm{Mg}^{++}$或いは $\mathrm{Mg}^{++}+\mathrm{Ca}^{++}$，その他の

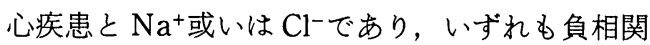
である。 
循環系疾患の標準化死亡比の高低を説明する飲 用水中の各イオンの関連性を見るために, SAS 統 計パッケージ PROC REG のステップワイズ法に よる重回帰分析を96市町村単位で試みた。水中イ オンに関する10項目の説明変量のらち，採択基準 . $\mathrm{P}=0.15 て ゙$, 脳血管障害については, $\mathrm{Ca}^{++}$と $\mathrm{Ca}^{++}-\mathrm{Na}^{+}$がプラス因子, $\mathrm{Cl}^{-}$がマイナス因子で

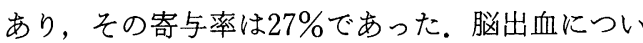

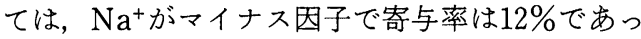

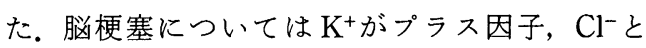
$\mathrm{Na}^{+} / \mathrm{K}^{+}$がマイナス因子であり，その寄与率は 18\%であった。高血圧性疾患については, $\mathrm{Cl}^{-}$がマ イナス因子で寄与率は $4 \%$ であった。虚血性心疾 患については, $\mathrm{Mg}^{++}+\mathrm{Ca}^{++}$と $\mathrm{Mg}^{++} / \mathrm{Ca}^{++}$がマイ ナス因子で寄与率は $16 \%$ であり，その他の心疾患 については $\mathrm{Ca}^{++}$と $\mathrm{Na}^{+} / \mathrm{K}^{+}$がマイナス因子とし て採用され，その寄与率は $7 \%$ であった。

\section{IV 考察}

泊ら（1988）はさきに鹿児島県における昭和 43 年から 57 年末での 15 年間の各種循環系疾患の SMR 值を特性値とした市町村のクラスター分析 から，循環系疾患死亡率の地理分布の類型化を行 ない，各種の民力指標との関連を調べたところ， 脳出血の死亡率は高血圧者の割合と強く連動し, 農村或いは過疎地域としての特性を持つ地域に高 いことを認めた。 また，虚血性心疾患及び脳梗塞 の死亡率は都市部に高く, 高血圧性疾患の死亡率 は離島地域に高いことも併せて指摘している。今 回の研究でも，各種循環系疾患の死亡パタンに共 通性のある市町村をまとめると，いくつかの群に 分類され，離島地域では総ての循環系疾患，特に 脳梗塞，虚血性心疾患の死亡率が低く，農山村を 多く含む群ではそれらの死亡率が高い特徵が見ら れた。泊らが用いた資料と今回の資料では 3 年の ずれがあることと，循環系疾患の分類に違いがあ るため，群分けされた市町村に食い違いが生じ， 今回得られた死亡パタンは泊らの場合と違うけれ ども, 本研究では, これら死亡率の特徵に対し, 飲用水のイオン濃度との関わりについて検討し
た。

水質と或る種の疾患や平均余命との関係につい ては，河川水中の化学物質と脳血管疾患死亡率と の関係について分析した小林（1957）の論文を初 めとして数多くの報告があるが，その結果は様々 である、 $\mathrm{Ca}^{++}$との関連を研究したものとしては， 脳血管障害の死亡率との間に負相関が見られると する報告が日本及び諸外国に怙いて多数見られる （小林：1957, Schroeder：1974, Morris et al： 1961, Comstock：1979). 本研究の場合には, $\mathrm{Ca}^{++}$ 濃度と脳血管障害死亡率との間に有意の負相関が 認められ, 重回㷌分析でも $\mathrm{Ca}^{++}$はその他の心疾患 死亡のマイナス因子として採用された. $\mathrm{Ca}^{++}$寿 命との間に正相関を見出したとする角南（1987） の報告があるが, これは水中 $\mathrm{Ca}^{++}$濃度の高いこと で成人病の代表でもある脳血管障害死亡などが少 なくなり，寿命の延長につながったものと理解さ れる． $\mathrm{Mg}^{++}$濃度の場合にも角南 (1987) は寿命と の間で正相関を見出しているが，本研究の場合に は， $\mathrm{Mg}^{++}$之虚血性心疾患死亡率との間で有意の 負相関が得られた。臨床的には本態性高血圧疾患 者に $\mathrm{Mg}^{++}$投与で血圧の降下を認めた報告（福崎 ら：1987)があるが, 水道水中の $\mathrm{Mg}^{++}$と循環系疾 患死亡率との相関を調べた報告は見当たらない。

本研究では又, $\mathrm{Mg}^{++}+\mathrm{Ca}^{++}$虚血性心疾患死 亡率との間に有意の負相関がみられた. $\mathrm{Mg}^{++}+$ $\mathrm{Ca}^{++}$は WHO の報告書では, 一応水の硬度として 決定されるとしている。この硬度を規定する因子 は基本的には $\mathrm{Ca}^{++}$量であり, 水の硬度と心血管 系疾患の死亡率とは負相関するとする報告が比較 的多い (Schroeder : 1974, Morris et al : 1961, Biörck et al : 1965, Neri et al : 1971). 仲村 5 （1988）は沖縄県にお拈調査で，水の硬度が高け れば脳血管障害死亡率が低いといら所見を得て括 り，我々の結果と同様である。しかし一方，これ を否定した報告も幾つか見られる（Lindeman et al : 1964, Elwood : 1971).

领用水の各イオンの比やイオン量の差を指標と して死亡率や寿命との関係をみた場合について は, $\mathrm{Na}^{+} / \mathrm{K}^{+}$の值が大きいとき, 脳卒中, 高血圧性 
疾患の死亡率が高く, 動脈硬化性心疾患の死亡率 が低いという野瀬（1976）の報告がある。しかし， 寿命との関係では有意相関はなかったと角南は報 告している，我々の場合は，市町村単位では脳血 管障害, 脳梗塞で有意の負相関がみられたが, 群 単位では群数が 5 と少ないため有意とは云えな かった、 $\mathrm{Ca}^{++} / \mathrm{K}^{+}$については角南の場合, 寿命と の相関がなかったと述べている，我々の場合も， この比と有意の相関を見た疾患はなく, 他にもこ の比の意義を疾患レベルで論じた報告はないよう である. $\mathrm{Ca}^{++}-\mathrm{Na}^{++}$は, この值の大小と $\mathrm{pH}$ 值は 正比例の関係にあり，その值の大きいところは中 性〜アルカリ性を示し，小さいところは弱酸性 ～強酸性を示す指標であり，野瀬は心疾患を伴う 高血圧性疾患死亡率とは負相関であったことを報 告し, 石原 (1961) は長寿村は短命村に比べて河 川水中の $\mathrm{Ca}^{++}-\mathrm{Na}^{+}$值が大さいことを報告して いる，我々の調査では，正負を問わず相関が有意 の疾患死亡はなかった。

いずれにしても，水中イオン濃度と各種疾患死 亡率との関係を見た場合, 調査対象地域によって 相関ありとするもの,なしとするもの様々である. 特に外国の調査例では, 水中イオン濃度の值が, $\mathrm{Na}^{+}$であれ $\mathrm{Ca}^{++}$であれ, 本研究の対象とした鹿児 島県のレベルに比べて極めて高い地域を含めて対 比させているものが多い，その中でも有意相関の 有無，相関の正負など，まちまちの結果しか得ら れていない，このことは，水分摂取が継続的にな されていても，必ずしも疾患と結びつくものでは ないことを意味するのであろら.例えば, $\mathrm{Na}^{+} か ゙$ 全 て $\mathrm{NaCl}$ として存在したと仮定しても, 日本では, 1 人 1 日あたり 1 日ットルの水を飲用し，これが 完全に吸収されても，全体の塩分摄取量の $0.2 \sim 0.4 \%$ と少なく，これが高血圧を基礎疾患と する循環系疾患の死亡率にまで影響するとは考古 難い.

しかしながら，血圧值そのものと飲用水のイオ ン濃度との関連については幾つかの報告が見らら れる. 血圧值と飲用水の $\mathrm{Na}^{+}$濃度との関係では, Fatula (1967) はソ連のアレクサンドロフスク（水
中 $\mathrm{Na}^{+}$濃度は $10.25 \mathrm{mEq} / \mathrm{L}$ ）に住む14歳以上の成 人で， $\mathrm{Na}^{+}$と血圧との間に正相関を見ており， Steinbach ら (1974)もルーマニアの漁村ジュリロ フカ(平均水中 $\mathrm{Na}^{+}$濃度 $13.22 \mathrm{mEq} / \mathrm{L}, \mathrm{K}^{+}$濃度 $0.12 \mathrm{mEq} / \mathrm{L}, \mathrm{Ca}^{++}$濃度 $\left.7.53 \mathrm{mEq} / \mathrm{L}\right)$ と首都ブカレ スト (平均水中 $\mathrm{Na}^{+}$濃度 $4.69 \mathrm{mEq} / \mathrm{L}, \mathrm{K}^{+}$濃度 0.02 $\mathrm{mEq} / \mathrm{L}, \mathrm{Ca}^{++}$濃度 $2.0 \mathrm{mEq} / \mathrm{L}$ ) に住む $40 \sim 60$ 歳の 男性を対比して，前者地区に住む者の方が血圧が 高いことを指摘している。また，小中学生の血圧 を調査したものとしては, Tuthill ら (1980, 1981) の米国マサチューセッッ（水中 $\mathrm{Na}^{+}$濃度 4.697 $\mathrm{mEq} / \mathrm{L} \sim 0.347 \mathrm{mEq} / \mathrm{L})$ での調査, Hofman ら (1980) のオランダ $\left(\mathrm{Na}^{+}\right.$濃度10 20mEq/L) での 調查があり，いずれも $\mathrm{Na}^{+}$と血圧値との間に正相 関を認めている。これらは, 水中 $\mathrm{Na}^{+}$濃度が極め て高い地域を含んで括り，飲用水由来の $\mathrm{Na}$ 摂取 量は無視できない量になったものと考方る。一方, Punsar ら (1975)はフィンランドの東西地区 $\left(\mathrm{Na}^{+}\right.$ 濃度は東地区 $0.374 \mathrm{mEq} / \mathrm{L}$, 西地区 $1.052 \mathrm{mEq} / \mathrm{L}$ ) 間で50〜69歳の男性の血圧を比較したところ差が 見られなかったとしている.更に, Bierenbaum ら （1975）のカンザス市 $\left(\mathrm{Na}^{+}\right.$濃度1.08 2mEq/L) の成人についての調査ではむしろ $\mathrm{Na}^{+}$と血圧と の間に負相関を認めている. Hallenbeck ら (1981) のイリノイ州 $\left(\mathrm{Na}^{+}\right.$濃度 $4.654 \mathrm{mEq} / \mathrm{L}$ $\sim 0.347 \mathrm{mEq} / \mathrm{L})$ の中高生を対象とした調查では $\mathrm{Na}^{+}$は払張期血圧とは正, 収縮期血圧とは負の相 関があるという報告もある。本研究の重回帰分析 の結果でも， $\mathrm{Na}^{+}$は脳出血死亡率にとって寄与率 12\%のマイナス因子になって扬，基礎疾患とし ての高血圧に影響するような濃度でないことを裏 付けている.

ともあれ, 本研究の対象とした鹿児島県では地 域間では循環系疾患死亡内容に差が見られ，この 差は飲用水のイオン濃度とある程度関連している ことが認められた。しかしながら，寄与率が小さ いことから他の環境要因などにも説明可能な事由 を求めるべきであろう. 


\section{V 結 U゙}

昭和 46 年から 60 年までの 15 年間の死亡統計か ら, 鹿児島県下 96 市町村のそれぞれについて, 種々 の循環系疾患の SMR を求め，それを特性值とし て市町村のクラスター分析を行なった．各クラス ターの特徵を飲料水のイオン濃度との関係で説明 を試みた。結果は以下の如くである。

1）クラスター分析の群分け基準を 7.5 としたと き，96市町村は大別して 5 群 $(\mathrm{I} \sim \mathrm{V})$ に分類さ れた。それぞれの群は，循環系疾患死亡パタンが 類似した市町村の集合と見ることが出来るＩI 群 は33市町村, II 群は16, III群は25, IV群は11, V 群が11町村であり, IV群の町村はすべて離島にあ る.

2）脳血管障害の SMR は I，II，III群では 1 以 上, IV, V群では 1 より低い. 脳出血の SMR はII 群では 2 以上，I，III，V群では 1 以上，IV群で は 1 より低い。高血圧性疾患では, V 群の SMR は 2 以上，I，II，III群では 1 以上，IV群では 1 末 満であった，虚血性心疾患の SMR はIII群のみ 1 以上で他の群では 1 より低く，その他の心疾患の SMR はIV群のみ 1 末満で, 他の 4 群では 1 以上 であった.したがって, III群の SMR 值はすべて 1 以上，IV群ではすべて1末満である.

3）群単位では, 脳血管障害死亡率は飲料水中 $\mathrm{Mg}^{++}, \mathrm{Ca}^{++}, \mathrm{Mg}^{++}+\mathrm{Ca}^{++}, \mathrm{Ca}^{++} / \mathrm{K}^{+}$と負相関, 虚血性心疾患死亡率は $\mathrm{Mg}^{++}, \mathrm{Mg}^{++}+\mathrm{Ca}^{++}$と負 相関，その他の心疾患は $\mathrm{Na}^{+}, \mathrm{Mg}^{++}, \mathrm{Ca}^{++}, \mathrm{Cl}^{-}$, $\mathrm{Mg}^{++}+\mathrm{Ca}^{++}$負相関を示した。市町村単位では 相関が有意となった疾患死亡率とイオン濃度の組 み合わせは多いが, 群単位の場合と重複したのは, 脳血管障害と $\mathrm{Ca}^{++}, \mathrm{Mg}^{++}+\mathrm{Ca}^{++}, \mathrm{Ca}^{++} / \mathrm{K}^{+}$, 虚 血性心疾患々 $\mathrm{Mg}^{++}, \mathrm{Mg}^{++}+\mathrm{Ca}^{++}$, その他の心疾 患と $\mathrm{Na}^{+}, \mathrm{Cl}^{-}$であった。

4）重回帰分析を行なったところ, 脳血管障害に ついては $\mathrm{Ca}^{++}$と $\mathrm{Ca}^{++}-\mathrm{Na}^{+}$がプラス因子, $\mathrm{Cl}^{-}$が マイナス因子であった。脳出血では $\mathrm{Na}^{+}$がマイナ ス因子であり，脳梗塞では $\mathrm{K}^{+}$がプラス因子, $\mathrm{Cl}^{-}$ と $\mathrm{Na}^{+} / \mathrm{K}^{+}$がマイナス因子であった，高血圧性疾
患では $\mathrm{Cl}^{-}$が，虚血性心疾患では $\mathrm{Mg}^{++}+\mathrm{Ca}^{++}$と $\mathrm{Mg}^{++} / \mathrm{Ca}^{++}$が, その他の心疾患では $\mathrm{Ca}^{++}$と $\mathrm{Na}^{+} /$ $\mathrm{K}^{+}$がそれぞれマイナス因子として採用された。

なお，本論文の投稿に際し，公益信託児玉記念基礎 医学研究助成基金の助成を受けた。

\section{文献}

Bierenbaum, M.L., et al. (1975): Possible toxic water factors in coronary heart-disease, Lancet, 1008-1010

Biörck, G., Bostrom, H. \& Windstkrom, A. (1965) : On the relationship between water hardness and death rate in cardiovascular disease, Acta Med. Scand., 178, 239-252

Comstock, G.W. (1979): Reviews and commentary, Water hardness and cardiovascular diseases, Am. J. Epidemiol., 110, 315-400

Elwood, P.C., et al. (1971): Cardiovascular surveys in areas with different water supplies, $\mathrm{Br}$. Med. J., 362-363

Fatula, M.I.(1967) : Incidence of arterial hypertension among persons having consumed water with an elevated sodium chloride level, Sov. Med., 30, $134-136$

福崎 恒, 他（1987）：マグネシウムの降圧効果に関 する研究, 日内会誌, 76, 283

Hallenbeck, W.H., Brenniman, G.R. \& Anderson, R. J. (1981): High sodium in drinking water and its effect on blood pressure, Am. J. Epidemiol., $114,817-826$

Hofman, A., Valkenburg, H.A. \& Vaandrager, G.J. (1980): Increased blood pressure in school children related to high sodium levels in drinking water, J. Epidemiol. Comm. Health, 34, 179-181

石原房雄（1961）：いわゆる長寿村と短命村の土壤並 びに河川水質の比較，日本衛生誌，16,142-149

Kobayashi, J. (1957): On geographical relationship between the chemical nature of river water and death-rate from apoplexy, (Prelimianry report), Berichite Ohara Inst. Landw. Forsch., 11, $12-21$

国民衛生の動向（1988）：厚生の指標，昭和63年度, 厚生統計協会, 東京

Lindeman, R.D. \& Assenzo, J.R. (1964): Correlation between water hardness and cardiovascular deaths in Oklahoma counties, Am. J. Public. Health, 54, 1071-1077

Morris, J.N., Crawford, M.D. \& Heady, J.A. (1961): 
Preliminary communication, hardness of local water supplies and mortality from cardiovascular disease in the county boroughs of England and Wales, Lancet, I, 860-862

仲村 薰, 他 (1988)：沖縄県に括ける飲料水の硬度 扣よびケイ酸と脳血管疾患死亡率との関係, 民族衛 生, 54, 92-98

Neri, L.C., Hewitte, D. \& Mandel, J.S. (1971): Risk of sudden death in soft water areas, Am. J. Epidemiol., 94, 101-104

野瀬善勝（1976）：领料水の硬度をめぐって一虚血性 心疾患之高血圧性疾患の土地集積性の差異一, 保健 の科学, 18, 265-273

Punsar, S., et al. (1975): Coronary heart disease and drinking water, a search in two Finish male cohorts for epidemiologic evidence of a water factor, J. Chron. Dis., 28, 259-287

Schroeder, H.A. \& Kraemer, L.A. (1974): Car- diovascular mortality, municipal water, and corrosion, Arch. Environ. Health, 28, 303-311

Steinbach, M., et al. (1974): On the ecology of arterial hypertension, Rev. Roum. Med., 12, 3-6

角南重夫（1987）：最近に拈ける我が国の平均余命の 都道府県各差と河川の水質との関係, 民族衛生, 53 , $68-73$

泊憞, 他 (1988)：鹿児島県における循環系疾患 の標準化死亡比の地域分布, 日本公衛誌, 35,159 $-165$

Tuthill, R.W., et al. (1980): The influence of naturally and artificially elevated levels of sodium in drinking water on blood pressure in school children, J. Environ. Path. Toxicol., 4, 173-181

Tuthill, R. \& Calabrese, E.J. (1981): Drinking water sodium and blood pressure in children: A second look, Am. J. Public. Health, 71, 722-729

（受稿 1989.7.5） 